\title{
Pengaruh Model Pembelajaran terhadap Sikap Ilmiah Mahasiswa dalam Pembelajaran Biologi
}

\author{
Al Khudri Sembiring \\ Universitas Lancang Kuning \\ E-mail: alkhudri_s@unilak.ac.id
}

\begin{abstract}
Abstrak
Pada proses pembelajaran cenderung berorientasi kepada dosen (teacher centered), model pembelajaran yang kurang bervariasi, bahkan cendrung menggunakan pembelajaran konvensional dengan ceramah di depan kelas, sehingga menyebabkan mahasiswa pasif, aktivitas masih tergolong rendah, dimana saat proses belajar mengajar berlangsung, sedikit sekali mahasiswa yang bertanya maupun mengemukakan pendapat. Penelitian ini untuk mengetahui pengaruh model pembelajaran (Project Based Learning, kooperatif tipe NHT dan konvensional) terhadap sikap ilmiah dalam pembelajaran biologi. Penelitian quasi eksperimen ini menggunakan desain penelitian randomized control-group posttest only design. Populasi penelitian adalah seluruh mahasiswa semester III dan terdapat tiga kelas paralel yang dipilih dengan teknik simple random sampling yaitukelas 3.1 menggunakanProject Based Learning, kelas 3.2 menggunakan model pembelajaran kooperatif tipe NHT, dan kelas 3.3 menggunakan pembelajaran konvensional. Uji persyaratan menunjukkan bahwa data terdistribusi normal dan homogen. Teknik analisis menggunakan teknik (One Way Anova) dan dilanjutkan dengan uji Tukey pada taraf signifikansi $\alpha=0,05$ dengan bantuan program SPSS 19.0diujikan dalam penelitian ini. Hasil penelitian terdapat pengaruh model pembelajaran terhadap sikap ilmiah mahasiswa dalam pembelajaran biologi, sikap ilmiah yang menggunakanmodel project based learning tidak berbeda signifikan dengan kelas yang menggunakanmodel kooperatif tipe NHT $(\mathrm{P}=0,138)$ tetapi berbeda signifikan dengan kelas konvensional $(\mathrm{P}=0,000)$. Berdasarkan hasil penelitian dapat disimpulkan bahwa terdapat pengaruh model pembelajaran (project based learning, kooperatif tipe NHT, dan konvensional) terhadap sikap ilmiah mahasiswa Program Studi Pendidikan Biologi Fakultas Keguruan dan Ilmu Pendidikan Univesitas Lancang Kuning Pekanbaru, Riau.
\end{abstract}

KataKunci: Project Based Learning, Kooperatif, NHT, Sikap Ilmiah

\section{The Effect of Learning Model on Students' ScientificAttitude in Biology Learning}

\begin{abstract}
In the learning process, teacher centered is always happened, less varied learning model, even learning are using conventional with lectures in front of the class, so as to cause passive students, activities are low, where during learning process, few students who ask and offer an opinion. This research was aimed to determine: the effect of learning model (Project Based Learning, cooperative NHT type and conventional) on students' scientificattitude in biology learning. A quasi-experimental research used randomized control-group posttest only design. The population in this study was all students from term IIIand there were three parallel classes choosen as the sample using cluster random sampling technique, 3.1students were being taught using Project Based Learning, 3.2students were being being taught with cooperative learning model NHT
\end{abstract}


type, and 3.3students were being taught with conventional learning model.The statistical assumtion test revealed that the data were normally distributed and homogeneous. The Analysis of One Way Variances (One Way ANOVA) followed by Tukey's test with a significance level $\alpha=0,05$ SPSS program version 19.0 were performed in this study. The result of this research showed that there is an effect of learning model on students' scientificattitude in biology learning, scientific attitude of students who were taught by project based learning model was not significaltly different than those who were taught by using cooperative learning model NHT type $(P=0.138)$, but was significantly different from conventional learning $(P=0.000)$. Based on the research we can conclude that is the kind of classroom ( project based learning, cooperative nht type, and conventionally) scientific attitude to education course biology students the teaching and un education science Universitas Lancang Kuning Pekanbaru, Riau

Keywords: Project Based Learning, Kooperatif, NHT, scientific attitude

\section{PENDAHULUAN}

\section{Latar Belakang}

Pendidikan adalah upaya membina serta mengembangkan kepribadian manusia secara rohani maupun jasmani. Ada juga pendapat ahli mengartikan pendidikan itu sebagai suatu proses pengubahan sikap dan tingkah laku seseorang maupunsekelompok orang dalam mendewasakan diri melalui pengajaran dan latihan. Kedewasaan dimaksud adalah mandiri dalam konteks kehidupan pribadinya, bermasyarakat, berbangsa dan bernegara, serta kehidupan sebagai makhluk tuhan. Salah satu cara untuk meningkatkan kualitas pendidikan bangsa ini adalah dengan meningkatkan proses pembelajaran, khususnya pada pembelajaran biologi. Biologi merupakan mata pelajaran yang terdapat di SMA yang mampu meningkatkan pengetahuan, keterampilan, sikap, dan nilai serta tanggungjawab kepada lingkungan, masyarakat, bangsa, negara yang beriman dan bertakwa kepada Tuhan Yang Maha Esa.

Menurut Dimyati dan Mudjiono (2015) Proses interaksi pembelajaran yang dimaksud bisa juga terjadi di dalam keluarga, sekolah, maupun lingkungan masyarakat. Interaksi tersebut bertujuan untuk meningkatkan perkembangan mental sehingga menjadi mandiri dan utuh. Hakikat kehidupan manusia hampir tidak pernah terlepas dari kegiatan belajar, baik secara individu, maupun dalam suatu kelompok tertentu. Sadar atau sadar, sesungguhnya sebagian besar aktivitas dalam kehidupan sehari-hari kita merupakan kegiatan belajar. Dengan demikian dapat kita katakan, tidak ada ruang dan waktu dimana manusia dapat melepaskan dirinya dari kegiatan belajar, dan itu berarti pula bahwa belajar tidak perna dibatasi usia, tempat maupun waktu, karena perubahan yang menuntut terjadinya aktivitas itu juga tidak perna berhenti (Aunurrahman, 2012).

Belajar merupakan suatu proses aktivitas yang terjadi pada individu dalam bentuk interaksi dengan lingkungan sekitar sehingga terjadi pengalaman belajar itu sendiri (Lufri, 2010). Belajar adalah suatu proses yang dilakukan individu untuk memperoleh suatu perubahan tingkah laku yang baru secara keseluruhan, sebagai hasil pengalaman individu itu sendiri di dalam interaksi dengan lingkungannya (Aunurrahman, 2012).

Proses pembelajaran biologi di kelas cendrung hanya mengantarkan mahasiswa pada pemahaman konsep saja. Salah satu perubahan yang dituntut dari proses pembelajaran biologi di kelas adalah sikap ilmiah mahasiswa. Sikap 
ilmiah dalam pembelajaran sains merupakan wujud dari nilai-nilai karakter yang dikembangkan dalam pembelajaran sebagai suatu sikap, sains terdiri dari berbagai sikap yang secara umum mengajarkan kepada mahassiswa tentang sikap manakala seseorang bekerja di dunia sains. Dengan begitu, Pelajaran IPA tidak hanya bertumpu pada pengetahuan yang berbasis hafalan, melainkan suatu proses atau aktivitas yang aktif menggunakan fikiran dalam menelaah gejala-gejala alam yang belum terpecahkan (Yusuf, 2010).

Dalam setiap rangkaian kegiatan pembelajaran dikelas seorang guru ataupun dosen harus mampu mengaktifkan pembelajaran yang dinamis.Sehingga siswa mampu menghayati materi secara langung maupun tidak langsung dengan sikap ingin tahu, sikap kritis, terbuka, jujur, bertanggung jawab baik mental maupun fisik sehingga pengalam yang didapat bisa diresapi dan bertahan lama (Yulianto, 2010).

Sikap ilmiah dapat dikembangkan ketika seseorang melakukan diskusi, percobaan, simulasi atau kegiatan dilapangan. Kegiatan-kegiatan ini secara langsung atau tidak akan mendidik mahasiswa untuk melalui proses sains (keterampilan proses).Melalui kegiatan ini siswa juga dituntut untuk bekerja sama dengan orang lain, sehingga untuk melaksanakan pekerjaan bersama, antar siswa harus kompak bekerja sama, disiplin, tanggung jawab akan tugas yang diberikan, menghormati keputusan bersama, menyampakan pendapat dengan santun, menghormati pendapat teman yang berbeda, dan masih banyak sikapsikap yang akan muncul selama proses pembelajaran (Riyanto, 2013).

Peserta didik dengan sikap ilmiah yang tinggi dan sedang memiliki keterampilan proses sains yang kuat, peserta didik lebih menyukai bidang- bidang yang membutuhkan keterampilanketerampilan dasar, cukup mampu bekerja sendirian dan kelompok, menyukai kecenderungan untuk mencapai prestasi lebih tinggi dari pada kecenderungan menghindari kegagalan, peserta didik selalu optimis akan berhasil dan cenderung mencapai prestasi yang maksimal. Hal ini sejalan dengan penelitian Maretasari (2012) bahwa hasil belajar yang tinggi mempunyai sikap ilmiah yang tinggi pula, begitu juga sebaliknya, hasil belajar yang rendah mempunyai sikap ilmiah yang rendah

Berdasarkan hasil observasi di kelas semester 3 Prodi Pendidikan Biologi FKIP Unilak dan hasil wawancara penulis dengan dosen biologi hal yang sama ditemui oleh penulis bahwa proses pembelajaran cendrung berorientasi kepada dosen (teacher centered), model pembelajaran yang kurang bervariasi, bahkan cendrung menggunakan pembelajaran konvensional dengan ceramah di depan kelas, sehingga menyebabkan mahasiswa pasif, aktivitas masih tergolong rendah, dimana saat proses belajar mengajar berlangsung, sedikit sekali mahasiswa yang bertanya maupun mengemukakan pendapat.

Salah satu usaha untuk mempengaruhi sikap ilmiah yaitu dengan menggunakan model Project Based Learning dan pembelajaran kooperatif tipe NHT. Berdasarkan penelitian Fakhruddin (2010), bahwa sikap ilmiah siswa selama proses pembelajaran dengan model pembelajaran kooperatif selama tiga kali pertemuan terdapat rerata sikap ilmiah mahasiswa mengalami peningkatan pada tiap pertemuan. Berdasarkan penelitian Wibowo (2013), menunjukkan bahwa peserta didik yang difasilitasi dalam proses pembelajaran berbasis proyek memiliki sikap yang jauh lebih tinggi daripada peserta didik yang hanya hanya 
mendapat pembelajaran secaran konvensional.

Berdasarkan pernyataan diatas, maka perlu adanya desain pembelajaran yang lebih menarik dan inovatif. Dalam hal ini yang berpusat kepada mahasiswa. Desain ini lebih menekankan pada proses pencarian pengetahuan daripada mentrasfer pengetahuan. Mahasiwa dilibatkan sebagai peranan penting serta aktif dalam menyikapi kejadian, sementara dosen sebagai pembimbing yang memfasilitasi serta mengkoordiasikan kegiatan mahawiswa.

\section{METODE}

Jenis pada penelitian quasi eksperimen.Dengan desain penelitian randomized control-group posttest only design. Populasi pada penelitian ini adalah merupakan seluruh mahasiswa semester 3 Prodi Pendidikan Biologi FKIP Unilak Pekanbaru, Riau tahun ajaran 2019/2020 terdiri atas 4 kelas aktif. Teknik pengambilan sampel dalam penelitian ini adalah simple random sampling, diperoleh kelas 3.1sebagai kelas eksperimen A denganProject Based Learning, kelas 3.2 eksperimen B dengan pembelajaran kooperatif tipe NHT, sedangkan kelas 3.3 yang menggunakan pembelajaran konvensional.

Kemudian sikap ilmiah siswa dapat diukur dengan menggunakan lembar observasi. Lembar observasi penelitian ini menggunan instrumen yang dikembangkan oleh Harlen dalam Anwar (2010) yang mana terdapat tujuh dimensi sikap, dengan masing-masing indikator kemunculan sikap ilmiah yaitu Curiosity (keingintahuan), Respect for evidence (respek terhadap data/fakta), Critial reflection (refleksi kritis), Perseverance (ketekunan), Creativity and inventiveness (kreatif dan penemuan), Open mindedness and Co-operation with others (berpikiran terbuka dan bekerjasama dengan orang lain) dan Sensitivity to environment (peka terhadap lingkungan).

Analisis data secara deskriptif dan analisis inferensial. Analisis inferensial dimulai dengan uji persyaratan, yang terdiri dari uji normalitas data menggunakan uji Kolmogorov-Smirnov pada taraf signifikansi $\alpha=0,05$ dan uji homogenitas data menggunakan Levene's pada taraf signifikansi $\alpha=0,05$. Data dianalisis menggunakan program SPSS for windows 19,00. Setelah uji persyaratan terpenuhi selanjutnya dilakukan pengujian hipotesis penelitian data hasil belajar siswa dianalisis menggunakan teknik analisis (One Way Anova) pada taraf signifikansi $\alpha=0,05$, dengan uji lanjut Tukey's test.

\section{HASILDAN PEMBAHASAN Hasil Penelitian}

Sikap ilmiah mahasiswa selama proses pembelajaran di kelas project based learning diperoleh nilai maximum 93 dan minimum 65 dengan $(\mathrm{x})^{-}$dan SD 77,76 $\pm 6,59$ menunjukkan data distribusi normal $(Z=0,122 ; \mathrm{P}=0,200)$. Pada kelas model kooperatif tipe NHT diperoleh nilai maximum 87 dan minimum 61 dengan $(\mathrm{x})^{-}$dan SD 74,41 $\pm 7,96$ serta data terdistribusi normal ( $\mathrm{Z}$ $=0,103 ; \quad \mathrm{P}=0,200), \quad$ dan kelas konvensional diperoleh nilai maximum 82 dan minimum 59 dengan $(\mathrm{x})^{-}$dan SD 69,67 $\pm 6,42$ serta data terdistribusi normal $(Z=0,125 ; P=0,200)$. Hasil uji homogenitas menunjukkan variasi data antara ketiga kelompok sampel dalam populasi adalah homogen $(\mathrm{F}=1,975 ; \mathrm{P}=$ 0,145).

Rata-rata standar deviasi yang diperoleh dari nilai sikap ilmiah mahasiswa dikelas project based learning, NHT, dan konvensional ditinjau dari aspek indikator adalah sebagai berikut sikap ilmiah siswa yang 
dibelajar dengan pembelajaran project based learning (SI1 87,46 \pm 10,55; SI2 $76,01 \pm 5,86 ;$ SI3 77, $18 \pm 8,4$; SI4 74,45 $\pm 8,23$; SI5 78,64 $\pm 8,77$; SI6 69,40 \pm 9,33; dan SI7 79,38 $\pm 6,39$ ) lebih tinggi dari pada model kooperatif tipe NHT (SI1 80,66 \pm 11 , 63; SI2 72,03 $\pm 5,68$; SI3 75,81 $\pm 8,24$; SI4 73,03 $\pm 10,42$; SI5 73,82 $\pm 11,16$; SI6 65,1 $\pm 8,73$; dan SI7 80,99 $\pm 6,88$ ) dan konvensional (SI1 $71,52 \pm 8,13$; SI2 70,55 $\pm 6,72$; SI3 $72,63 \pm 8,17$; SI4 67,80 \pm 7,5; SI5 67,13 $\pm 8,12$; SI6 59,03 $\pm 6,73$; dan SI7 79,54 $\pm 7,04)$ Gambar 1 .

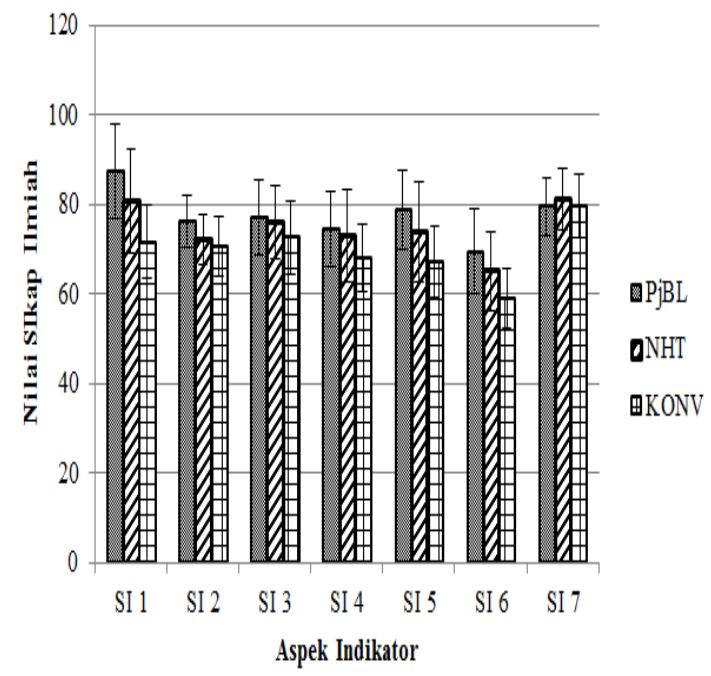

Gambar 1. Rata-rata Nilai Sikap Ilmiah Siswa Ditinjau Dari Aspek Indikator

Pengaruh model pembelajaran (project based learning, pembelajaran kooperatif tipe NHT dan pembelajaran konvensional) terhadap sikap ilmiah mahasiswa dalam pembelajaran biologi dianalisis menggunakan teknik analisis varians satu jalur (One Way Anova). Hasil data sikap ilmiah menunjukkan bahwa model pembelajaran (project based learning, pembelajaran kooperatif tipe NHT dan pembelajaran konvensional) secara signifikan berpengaruh terhadap sikap ilmiah mahasiswa $(\mathrm{F}=10,458 ; \mathrm{P}=0,000)$. Hasil uji Tukey's menunjukkan bahwa sikap ilmiah yang menggunakan model project based learning 77,76 $\pm 6,59\left((\mathrm{x})^{-}\right.$ \pm SD) tidak berbeda signifikan dengan menggunakan model kooperatif tipe NHT 74,41 $\pm 7,96\left((\mathrm{x})^{-} \pm \mathrm{SD}\right)(\mathrm{P}=$ $0,138)$ tetapi berbeda signifikan dengan kelas konvensional 69,67 $\pm 6,42\left((\mathrm{x})^{-} \pm\right.$ SD $)(\mathrm{P}=0,000)$. Sikap ilmiah mahasiswa yang menggunakan kooperatif tipe NHT berbeda signifikan dengan kelas konvensional $(\mathrm{P}=0,025)$ (Gambar dibawah ini).

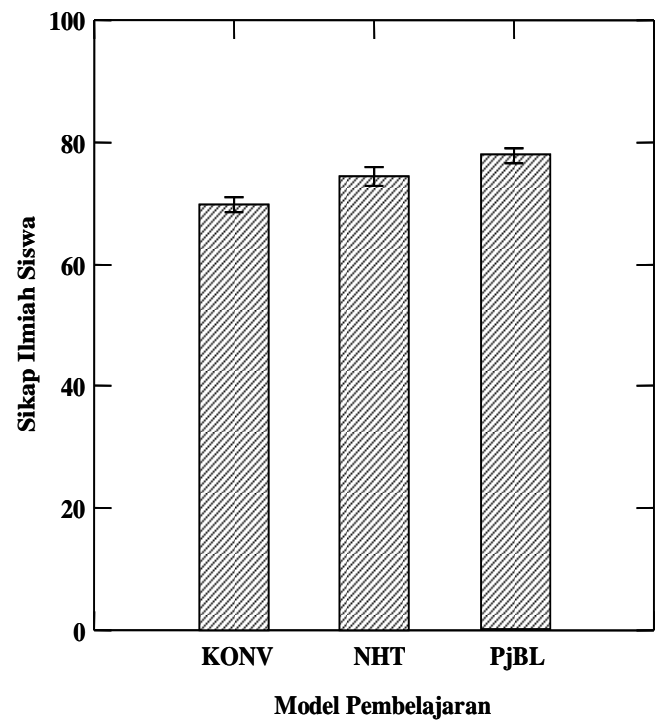

$\begin{array}{ll}\text { Gambar 2. } & \begin{array}{l}\text { Pengaruh } \\ \text { pembelajaran terhadap }\end{array} \\ & \text { sikap ilmiah mahasiswa }\end{array}$

\section{Pembahasan}

Sikap ilmiah pada idealnya menunjukkan kecenderungan seseorang dalam berpikir serta bertindak dengan caranalar ilmiah dalam mengerjakan sesuatu.Berdasarkandata sikap ilmiah diketahui bahwa rata-rata skor sikap ilmiah mahasiswa Prodi Pendidikan Biologi termasuk dalam kategori baik.Data juga menunjukkan bahwaratarata skor aspek tertinggi adalah aspek keingintahuan (Gambar 1).

Berdasarkan data yang di hasilkan bahwa terdapat pengaruh yang signifikan antara penggunaan model 
project based learning, model kooperatif tipe NHT dan konvensional terhadap sikap ilmiah mahasiswa dalam pembelajaran biologi. Selanjutnya hasil uji lanjut menunjukkan bahwa sikap ilmiah yang menggunakan model project based learning tidak berbeda signifikan dengan kelas yang menggunakanmodel kooperatif tipe NHT, tetapi berbeda signifikan dengan kelas konvensional, sedangkan sikap ilmiah mahasiswa dengan model kooperatif tipe NHT berbeda signifikan dengan kelas konvensional.Hasil penelitian ini senada dengan penelitian Susanti (2013), bahwa pembelajaran berbasis proyeklebih efektif meningkatkan sikap ilmiah siswa kelas XI IPA SMA Kabupaten Tasikmalaya, Jawa barat.Wibowo (2013), hasil penelitiannya mengungkapkan bahwa peserta didik yang difasilitasi pembelajaran berbasis proyek memiliki sikap lebih tinggi dari peserta didik yang difasilitasi pembelajaran konvensional. Sikap ilmiah dapat kembangkan melalui proses belajar, dalam model Project Based Learning peserta didik dilatih mengkonstruksi sendiri pengetahuannya sehingga dari kegiatan pembelajaran pesertadidik dapat membentuk sikap ilmiah.

Berdasarkan analisis data menunjukkan sikap ilmiah mahasiswa selama enam kali pertemuan, pada satu pokok bahasan sistem pernapasan lebih baik pada kelas project based learning dan kooperatif tipe NHT, dibandingkan pada kelas konvensional, data sikap ilmiah didapat dengan mengamati tingkah laku atau tindakan mahasiswa yang terlihat sesuai dengan indikator sikap ilmiah yang diamati pada setiap kali pertemuannya. Lebih tepatnya lagi sikap ilmiah mahasiswa yang menggunakan model pembelajaran project based learning dan kooperatif tipe NHT ini karena pada model ini mahasiswa terfasilitasi sikap ilmiahnya untuk berkembang. Hasil penelitian ini sejalan dengan hasil penelitian yang diperoleh Karle (2010) yang menunjukkan adanya korelasi yang positif dan signifikan antara sikap ilmiah mahasiswa dengan prestasi belajarnya.

Hasil penelitian ini sesuai dengan penelitian Fakhruddin (2010), bahwa sikap ilmiah siswa selama proses pembelajaran dengan model pembelajaran kooperatif selama tiga kali pertemuan rata-rata sikap ilmiah siswa mengalami peningkatan tiap pertemuan. Pada pertemuan pertama rata-rata skor sikap ilmiah siswa $77,8 \%$ berada pada kategori tinggi, pertemuan kedua meningkat menjadi $86,6 \%$ berada pada kategori tinggi, pada pertemuan ketiga terus meningkat menjadi $93,3 \%$ berada pada kategori tinggi.Dahar (2011) menyatakan bahwa belajar adalah suatu proses di mana suatu organisme berubah perilakunya sebagai akibat pengalaman, maka merupakansuatu hal yang wajar jika seorang siswa mengalami perubahan setelahmendapatkan proses pembelajaran tertentu sehingga prestasinya dapat meningkatdibandingkan sebelum memperoleh pembelajaran.

Menurut Hosnan (2014), pembelajaran berbasis proyek atau project based learning merupakan model pembelajaran yang menggunakan proyek atau kegiatan sebagai sarana pembelajaran untuk mencapai kompetensi sikap, pengetahuan dan keterampilan. Penekanan pembelajaran terletak pada aktivitas mahasiswa untuk memecahkan masalah untuk menerapkan keterampilan dalam meneliti, menganalisis, membuat, sampai dengan merepresentasikan hasil produk pembelajaran berdasarkan pengalaman nyata.

Model ini memperkenalkan kepada mahasiswa untuk bekerja secara mandiri ataupun berkelompok dalam 
mengkonstruksikan produk secara auntentik yang bersumber dari masalah yang nyata dalam kehidupan seharihari.Secara harfiah sikap ilmiah dapat dikembangkan melalui diskusi, percobaan, simulasi, atau kegiatan dilapangan. Selama kegiatan pembelajaran dengan model project based learning mahasiswa akan lebih mampu mengembangkan sikap ilmiahnya, karena setiap langkah pembelajaran project based learning memiliki potensi untuk mengembangkan sikap ilmiah secara alami.

Hasil penelitian ini searah dengan penelitian yang diperoleh Karle (2010) yang menunjukkan adanya korelasi yang positif dan signifikan antara sikap ilmiah mahasiswa dengan prestasi belajarnya. Penelitian Purwaningsih (2011) juga menyimpulkan adanya pengaruh sikap ilmiah siswa terhadap hasil belajar siswa. Performa seseorang dalam melakukan suatu tugas akan ditentukan oleh sikap karena sikap seseorang akan sangat mempengaruhi kompetensi untuk berhubungan dengan lingkungan sekitar. Sikap ilmiah yang baik yang ditunjukkan siswa selama proses pembelajaran dapat menghasilkan prestasi belajar yang baik pula. Hal ini senada dengan pendapat Dimyati dan Mudjiono (2010) yang menyatakan bahwa sikap merupakan salah satu faktor internal yang dapat mempengaruhi prestasi seseorang dalam belajar.

Berdasarkan pendapat tersebut maka sikap merupakan faktor dari dalam diri mahasiswa yang turut andil menentukan prestasi yang dapat ketika pembelajaran berlangsung.Sehingga sikap yang baik yang dimiliki oleh mahasiswa secara logis akan mempermudah penerimaan informasi terutama materi pelajaran, sehingga siswa lebih memahami materi yang diberikan dan pada akhirnya akan menunjukkanprestasi yang baik. Senada dengan pernyataan Gagne dalam Slameto (2010) bahwa sikap adalah hal yang penting dalam proses belajar, tanpa kemampuan ini belajar tidak akan berhasil dengan baik.

Slameto (2010) mengatakan sikap siswa adalah faktor yang mempengaruhi prestasi belajar siswa. Sikap merupakan sesuatu yang dipelajari, dan sikap menentukan bagaimana individu bereaksi terhadap situasi serta menentukan apa yang dicari individu dalam kehidupan. Sikap kemudian mendasari dan mendorong ke arah sejumlah perbuatan yang satu sama lainnya berhubungan. Dengan demikian dapat dilihat bahwa sikap ilmiah yang ditunjukkan siswa akan berhubungan dengan prestasi belajarnya.

Hasil penelitian ini juga mendukung pendapat Syah (2011) mengenai respon positif siswa, yang berarti siswa dengan sikap ilmiah yang positif pada umumnya akan memperoleh dampak yang positif pula terhadap prestasi belajarnya sebagai representasi usaha-usaha yang telah dilakukannya selama proses pembelajaran. Sebaliknya jika sikap ilmiah siswa cenderung negatif maka pada umumnya prestasi belajarnya tidak akan sebagus siswa yang sikap ilmiahnya positif.

Rusman (2012) menyatakan bahwa model pembelajaran kooperatif tipe NHT memiliki beberapa kelebihan antara lain: 1) setiap siswa menjadi siap; 2) siswa dapat melakukan diskusi dengan sungguhsungguh; 3) siswa yang pandai dapat mengajari siswa yang kurang pandai. Sedangkan pada model kooperatif tipe NHT merupakan suatu model yang mengutamakan adanya kelompok kerja, mengutamakan kerja sama tim dalam menyelesaikan permasalahan untuk menerapkan pengetahuan dalam langkah mencapai tujuan pembelajaran secara bersama. Setiap anggota kelompok memberikan 
sumbangan terhadap anggota kelompok, para mahasiswa juga diberikan kesempatan bersosialisasi, dengan demikian akan menjadi wadah mengembangkan sikap ilmiah siswa.Salah satu prinsip yang harus diperhatikan dalam meningkatkan pemahaman siswa menurut Slameto (2010) yaitu memberi dorongan dan membimbing siswa untuk melakukan penemuan sendiri. Penggunaan model Siklus Belajar 5E dapat menjadi salah satu alternatif yang tepat karena model ini menekankan pada penemuan konsep sendiri oleh siswa.

Hasil penelitian juga sejalan dengan penelitian Sukaryono (2013) penerapan pembelajaran kooperatif Team Games Tournament tidak lebih baik dari penerapan pembelajaran kooperatif Number Heads Together.Selanjutnya pada model pembelajaran kooperatif tipe NHT bahwa rata-rata nilai sikap ilmiah pada model pembelajaran ini lebih tinggi dibandingkan model konvensional, karena pada model ini setiap tahapantahapan model ini juga memfasilitasi berkembangnya sikap ilmiah siswa. Adapun langkah pembelajaran yaitu penomoran, mengajukan pertanyaan, berpikir bersama, dan menjawab, setiap siswa dituntut untuk berperan aktif selama proses pembelajaran (Lufri, 2010). Sedangkan pada kelas konvensional siswa hanya pasif dan guru yang lebih aktif menjelaskan kepada siswa sehingga model ini tidak mampu memfasilitasi berkembangnya sikap ilmiah siswa

Dengan demikian siswa yang pandai dapat mengembangkan kemampuan dan keterampilan yang dimilikinya.Sedangkan siswa yang lemah akan terbantu dalam memahami materi pembelajaran sehingga akan meningkatkan hasil belajarnya.

Menurut Komalasari (2010) “model Team Games Tournament (TGT) merupakan salah satu tipe atau model pembelajaran kooperatif yang mudah diterapkan, melibatkan aktivitas seluruh siswa tanpa harus ada perbedaan status, melibatkan peran siswa sebagai tutor sebaya dan mengandung unsur permainan serta reinforcement.

Berbeda dengan model konvensional yang menggunakan metode ceramah, dimana siswa terlihat pasif karena hanya menjadi pendengar yang baik dan bertanya apabila diminta guru bertanya, dalam model konvensional sikap ilmiah siswa tidak terwadahi untuk berkembang karena peran siswa hanya duduk diam dan mendengarkan penjelasan dari guru.

Sikap ilmiah siswa dapat dikelompokkan berdasarkan setiap aspek indikator, rata-rata nilai sikap ilmiah siswa pada kelas project based learning, model kooperatif tipe NHT dan konvensional ditinjau dari aspek indikator dapat dilihat pada Gambar 1. Indikator pertama yaitu Curiosity (keingintahuan). Pada aspek ini ada empat kegiatan siswa yang dinilai yaitu dengan tingkah laku atau tindakan siswa yang terlihat dengan kebiasaan antusias mencari jawaban, fokus terhadap tugas yang sedang dikerjakan, antusian pada proses sains dan menanyakan setiap langkah kegiatan, berdasarkan rata-rata sikap ilmiah siswa bahwa kelas project based learning lebih tinggi dibandingkan kelas model kooperatif tipe NHT dan konvensional.

Indikator kedua yaitu Respect for evidence (respek terhadap data/fakta). Pada aspek ini ada lima kegiatan siswa yang dinilai yaitu dengan tingkah laku atau tindakan siswa yang terlihat dengan kebiasaan objektif/jujur, tidak memanipulasi data, tidak purbasangka (saling curiga), mengambil keputusan sesuai fakta, dan tidak mencampurkan fakta dengan pendapat, berdasarkan ratarata sikap ilmiah siswa bahwa kelas 
project based learning lebih tinggi dibandingkan kelas model kooperatif tipe NHT dan konvensional.

Indikator ketiga yaitu Critial reflection (refleksi kritis). Pada aspek ini ada empat kegiatan siswa yang dinilai yaitu dengan tingkah laku atau tindakan siswa yang terlihat dengan kebiasaan meragukan temuan teman, menanyakan setiap perubahan atau hal baru, mengulangi kegiatan yang dilakukan, dan tidak mengabaikan sumber informasi meskipun kecil, berdasarkan rata-rata sikap ilmiah siswa bahwa kelas project based learning lebih tinggi dibandingkan kelas model kooperatif tipe NHT dan konvensional.

Indikator keempat yaitu Creativity and inventiveness (kreatif dan penemuan). Pada aspek ini ada enam kegiatan siswa yang dinilai yaitu dengan tingkah laku atau tindakan siswa yang terlihat dengan kebiasaan menggunakan fakta-fakta untuk dasar konklusi (simpulan), menunjukkan laporan berbeda dengan teman kelas, merubah pendapat dalam merespon terhadap fakta, menggunakan alat tidak seperti biasanya, mengemukakan ide-ide baru, dan menguraikan simpulan/pendapat baru hasil pengamatan, berdasarkan rata-rata sikap ilmiah siswa bahwa kelas project based learning lebih tinggi dibandingkan kelas model kooperatif tipe NHT dan konvensional.

Indikator kelima yaitu Open mindedness and Co-operation with others (berpikiran terbuka dan bekerjasama dengan orang lain). Pada aspek ini ada enam kegiatan siswa yang dinilai yaitu dengan tingkah laku atau tindakan siswa yang terlihat dengan kebiasaan menghargai pendapat atau temuan orang lain, mau merubah pendapat jika data/sumber informasi kurang, menerima saran dari teman, tidak merasa selalu benar, menganggap setiap kesimpulan adalah tentatif (masih dapat berubah) dan berpartisipasi aktif dalam kelompok, berdasarkan rata-rata sikap ilmiah siswa bahwa kelas project based learning lebih tinggi dibandingkan kelas model kooperatif tipe NHT dan konvensional.

Indikator keenam yaitu Perseverance (ketekunan). Pada aspek ini ada tiga kegiatan siswa yang dinilai yaitu dengan tingkah laku atau tindakan siswa yang terlihat dengan kebiasaan selalu mencari sumber informasi lain untuk melengkapi informasi yang sudah ada, mengulangi pekerjaan meskipun berakibat kesalahan, dan fokus terhadap pekerjaan sendiri meskipun teman sekelasnya selesai lebih awal, berdasarkan rata-rata sikap ilmiah siswa bahwa kelas project based learning lebih tinggi dibandingkan kelas model kooperatif tipe NHT dan konvensional.

Indikator ketujuh atau indikator terakhir yaitu Sensitivity to environment (peka terhadap lingkungan). Pada aspek ini ada tiga kegiatan siswa yang dinilai yaitu dengan tingkah laku atau tindakan siswa yang terlihat dengan kebiasaan perhatian terhadap peristiwa yang terjadi disekitar, partisipasi pada kegiatan sosial, dan menjaga kebersihan lingkungan sekolah, berdasarkan rata-rata sikap ilmiah siswa bahwa kelas model kooperatif tipe NHT lebih tinggi dibandingkan kelas project based learning dan konvensional.

Berdasarkan ketujuh indikator, ada enam indikator sikap ilmiah siswa yang rata-rata nilai siswa model project based learning lebih tinggi dibandingkan rata-rata nilai siswa model model kooperatif tipe NHT dan konvensional, dan pada satu indikator yaitu indikator Sensitivity to environment (peka terhadap lingkungan) rata-rata nilai model numbered heads together lebih tinggi dibandingkan model project based learning dan konvensional. Irfan (2012) melakukan penelitian terhadap siswa 
yang menggunakan model pembelajaran Cooperative tipe Numered Heads together (NHT) dan model pembelajaran konvensional. Dari hasil penelitiannya model pembelajaran cooperative tipe Numered Heads Together (NHT) lebih baik di bandingkan dengan model pembelajaran konvensional.

Rina et al (2012). menyatakan bahwa siswa yang memiliki sikap ilmiah yang tinggi dan sedang akan lebih mudah dalam menguasai dan menjelaskan materi pelajaran kepada teman-temannya, sementara siswa yang memiliki sikap ilmiah yang rendah akan mengalami kesulitan dalam belajar sehingga sulit menguasai materi pelajaran

Lebih tingginya rata-rata nilai pada kelas project based learning tidak terlepas dari tahapan-tahapan pelaksanaan model pembelajaran ini, setiap tahapan pelaksanaan memfasilitasi setiap indikator sikap ilmiah yang dinilai. Adapun langkah pembelajarannya yaitu pertanyaan mendasar, penentuan proyek, perencanaan langkah-langkah penyelesaian proyek, penyusunan jadwal pelaksanaan proyek, penyelesaian proyek dengan fasilitas dan monitoring guru, penyusunan laporan dan presentasi/publikasi hasil proyek, dan evaluasi proses dan hasil proyek, yang setiap tahapan ini memerlukan partisipasi dan keaktifan siswa secara tidak langsung memfasilitasi berkembangnya sikap ilmiah siswa.

Selanjutnya pada model pembelajaran kooperatif tipe NHT bahwa rata-rata nilai sikap ilmiah pada model pembelajaran ini lebih tinggi dibandingkan model konvensional, karena pada model ini setiap tahapantahapan model ini juga memfasilitasi berkembangnya sikap ilmiah siswa.
Adapun langkah pembelajaran yaitu penomoran, mengajukan pertanyaan, berpikir bersama, dan menjawab, setiap siswa dituntut untuk berperan aktif selama proses pembelajaran (Lufri, 2010). Sedangkan pada kelas konvensional siswa hanya pasif dan guru yang lebih aktif menjelaskan kepada siswa sehingga model ini tidak mampu memfasilitasi berkembangnya sikap ilmiah siswa.

Adapun langkah pembelajarannya yaitu pertanyaan mendasar, penentuan proyek, perencanaan langkah-langkah penyelesaian proyek, penyusunan jadwal pelaksanaan proyek, penyelesaian proyek dengan fasilitas dan monitoring guru, penyusunan laporan dan presentasi/publikasi hasil proyek, dan evaluasi proses dan hasil proyek, yang setiap tahapan ini memerlukan partisipasi dan keaktifan siswa secara tidak langsung memfasilitasi berkembangnya sikap ilmiah siswa.

\section{KESIMPULAN \\ Kesimpulan}

Berdasarkan hasil penelitian dan pembahasan yang telah diuraikan, maka dapat disimpulkan bahwa terdapat pengaruh model pembelajaran (project based learning, kooperatif tipe NHT, dan konvensional) terhadap sikap ilmiah mahasiswa Program Studi Pendidikan Biologi Fakultas Keguruan dan Ilmu Pendidikan Univesitas Lancang Kuning Pekanbaru, Riau.

\section{Saran}

Penelitian ini diharapkan dapat menjadi acuan penelitian bagi peneliti selanjutnya, dan peneliti selanjutnya dapat menghubungkan aspek-aspek penelitan berikutnya.

1. Bagi Mahasiswa, Berdasarkan dari hasil penelitian yang telah dilakukan dan mengetahui kendala yang ada, dapat disarankan kepada peserta didik 
:a. Memanfaatkan waktu belajar sebaik mungkin b. Menggunakan fasilitas yang memadai untuk melakukan praktikum c. Melakukan diskusi kelompok guna mengembangkan keterampilan proses sains dan sikap ilmiah.

2. Bagi Dosen, Berdasarkan dari hasil penelitian yang telah dilakukan, disarankan kepada para dosen: a. Menerapkan model pembelajaran (project based learning, kooperatif tipe NHT dalam pembelajaran yang dapat meningkatkan keterampilan sikap ilmiah mahasiswa. b. Menentukan pembelajaran yang sesuai dengan karakteristik siswaMampu mengevaluasi hasil belajar peserta didik sampai mengukur sikap ilmiah.

3. Bagi Peneliti lain, Berdasarkan dari hasil penelitian yang telah dilakukan, disarankan kepada peneliti yang lain: a. Agar benar-benar memahami apa itu model pembelajaran inkuiri terbimbing sehingga peneliti dapat melanjutkan penerapan model pembelajaran (project based learning, kooperatif tipe NHT dengan maksimal dan mendapatkan hasil yang memuaskan untuk menilai sikap ilmiah.

\section{DAFTAR PUSTAKA}

Anwar (2010).Penilaian Sikap Ilmiah Dalam Pembelajaran Sains. Jurnal Pelangi Ilmu, Vol.2, No.5 : 103114.

Aunurrahman. 2012. Belajar dan Pembelajaran. Bandung: Alfabeta.
Dahar, Ratna Willis. 2011. Teori Belajar dan Pembelajaran. Jakarta: Penerbit Erlangga.

Dimyati dan Mudjiono. 2010. Belajar dan Pembelajaran. Jakarta: Rineka Cipta.

Fakhruddin, Eprina, E,.dan Syahril. 2010. Sikap Ilmiah Siswa dalam Pembelajaran Fisika dengan Penggunaan Media Komputer Melalui Model Kooperatif Tipe STAD pada Siswa Kelas X3 SMA Negeri I Bangkinang Barat.Jurnal Geliga Sains, 4 (1): 18-22.

Hosnan.2014. Pendekatan Saintifik dan Kontekstual dalam Pembelajaran Abad 21. Bogor: Ghalia Indonesia.

Irfan, Bahtiar, 2012. Pengaruh Pola Komunikasi Organisasi Terhadap Lingkungan Kerja. Skripsi Tidak Publikasikan. Malang: Universitas Maulana Malik Ibrahim.

Karle, P. 2010. Hubungan antara Sikap Ilmiah dengan Prestasi Belajar Mahasiswa Program Studi BK FKIP Unisri Surakarta Semester Genap Tahun Akademik 2009/2010.Jurnal Unisri Volume XXIV No.1, Agustus Tahun 2012.

Komalasari, $\quad$ Kokom. 2010. Pembelajaran Kontekstual: Konsep dan Aplikasi. Refika Aditama. Bandung.

Lufri. 2010. Strategi Pembelajaran Biologi Teori, Praktek, dan Penelitian. Padang: Negeri Padang University Press.

Maretasari, B. Subali, Hartono. 2012. Penerapan Model Pembelajaran Inkuiri Terbimbing Berbasis 
Laboratorium Untuk

Meningkatkan Hasil Belajar Dan

Sikap Ilmiah Siswa”, UPEJ (1).

Purwaningsih, Iin. (2011). Pengaruh Intelegensi Dan Kreativitas Siswa Terhadap Prestasi Belajar Ekonomi Pada Siswa Kelas VIII Smp Negeri 1 Bendosari Sukoharjo Tahun Pelajaran 2010/2011. Skripsi Thesis, Universitas Muhammadiyah Surakarta

Riyanto, E. 2013.Sikap Ilmiah sebagai Implementasi Pendidikan Karakter Pada Pembelajaran Sains di Sekolah Dasar.Prosiding. Madiun: IKIP PGRI Madiun.

Rusman.2012.

Model-model

Pembelajaran: Mengembangkan Profesionalisme Guru. RajaGrafindo Persada: Jakarta.

Rina Astuti, Widha Sunarno, dan Suciati Sudarisman, "Pembelajaran IPA Dengan Pendekatan Keterampilan Proses Sains Menggunakan Metode Eksperimen Bebas Termodifikasi Dan Eksperimen Terbimbing Ditinjau Dari Sikap Ilmiah Dan Motivasi Belajar Siswa”. Jurnal Inkuiri,pasca UNS. Vol. 1 No. 1 (2012) h. 7

Slameto. 2010. Belajar dan Faktor-faktor yang Mempengaruhinya. Jakarta: Rineka Cipta.

Susanti. 2013. Pengaruh Pembelajaran Berbasis Proyek terhadap Kemampuan Berpikir Kreatif dan
Sikap Ilmiah Siswa pada Materi Nutrisi.Jurnal Pengajaran MIPA, 18 (1): 1-7.

Sukaryono. 2013. Eksperimentasi Model Pembelajaran NHT dan TGT Terhadap Prestasi Belajar Siswa. (Tesis). Universitas Muhammadiyah Purworejo. Purworejo.

Syah, Muhibbin. 2011. Psikologi Pendidikan, Bandung: Remaja Rosdakarya.

Wibowo, A.L.P. 2013. Peningkatan Sikap Serta Hasil Belajar Peserta Didik SMAN 9 Malang Melalui Metode Project Based Learning(PBL). Prosiding. Malang: Universitas Negeri Malang.

Yulianto, Achmad. 2010. Dualisme Penelitian Hukum Normatif dan Empiris. Yogyakarta: Pustaka Belajar.

Yusuf, Pawit M. 2010. Komunikasi Instruksional : teori dan praktek. Jakarta : PT. Bumi Aksara. 